\title{
İşgörenlerin Örgütsel Güven Algılarının Belirlenmesi: Üniversite Çalışanları Üzerinde Bir İnceleme*
}

\author{
Organizational Trust Perceptions of Employees: A Study on University \\ Employees
}

Bilm. Uzmanı Mehmet ÖNDER ${ }^{1}$, Dr. Öğr. Üyesi Ercan YAVUZ²

\begin{abstract}
Özet
Bu çalışmanın amacı devlet ve vakıf üniversitelerinde görev yapan idari işgörenlerin örgütsel güven düzeylerini belirlemek ve bu düzeylerin demografik değişkenlere göre farklılı̆̆ını ortaya koymaktır. Araştırmanın örneklemini 772 idari hizmet veren işgören oluşturmaktadır. Araştırma bulguları; frekans, $t$ testi ve tek yönlü varyans analizi kullanılarak değerlendirilmiştir. Bulgulara göre, çalışılan üniversite türüne göre, örgütsel güveni oluşturan tüm alt boyutlarda vakıf üniversitelerinde çalıșan idari işgörenlerin ortalama puanlarının daha yüksek olduğu ve istatistiksel olarak anlamlı bir farklılık yarattığı tespit edilmiş̧ir. Ayrıca katılımcıların medeni durum değişkeni işgörenlerin örgütsel güven algılarında farklılaşmaya sebep olmazken, gelir durumu değişkeninin farklılaşmaya sebep olduğu belirlenmiştir. Araştırmada kadın, ilköğretim mezunu ve göreve yeni başlayan işgörenlerin lehine, yöneticiye güven ile örgütün kendine güven boyutlarında farklılık olduğu belirlenmiştir. Öte yandan örgütün kendine güven boyutunda yaş, görev yapılan birim değişkenlerinde farklılık ortaya çıkmıştır. Statü değişkenine göre ise sadece yöneticiye güven boyutunda istatistiksel açıdan anlamlı bir farklılık saptanmıştır.
\end{abstract}

Anahtar Kelimeler: Güven, örgütsel güven, işgören

Makale Türü: Araştırma makalesi

\begin{abstract}
The purpose of this study is to determine the level of organizational trust of the administrative employee at state and foundation universities and to show whether these levels differ according to demographic variables. The sample of the study is composed of 772 administrative staff. The research findings were evaluated using frequency, $t$ test and one way ANOVA. As a result of the research, according to university type, it is found that the mean scores of administrative personnel working in foundation universities are higher at all sub dimensions forming the organizational trust and create statistically significant difference. Also, the fact that while the marital status variable of the participants does not cause differentiation in organizational trust perceptions of the personnel, income status causes differentiation is determined. Significant difference at director trust dimension and
\end{abstract}

\footnotetext{
* Bu çalışma, Gazi Üniversitesi, Eğitim Bilimleri Enstitü’sünde tamamlanan "Devlet ve Vakıf Üniversitlerinde Çalışan Personelin Örgütsel Güven Algıları: Ankara İli Örneği’” başlıklı yüksek lisans tez çalışmasından üretilmiştir.

${ }^{1}$ Gazi Üniversitesi, Eğitim Bilimleri Enststitüsü, mehmet.onder@ gazi.edu.tr, Orcid ID: https://orcid.org/0000-0002-0620-7331

${ }^{2}$ Ankara Hacı Bayram Veli Üniversitesi, Turizm Fakültesi, ercan.yavuz@hbv.edu.tr, Orcid ID: https://orcid.org/0000-00033696-4832 
organization's self reliability dimension of the woman, primary school graduate and new personnel is determined. On the other side, a significant difference has arisen in age, work unit variables at organization's self reliability dimension. According to status variance, on the other hand, a statistically significant difference is found only at director trust aspect.

Keywords: Trust, organizational trust, employee

Paper Type: Research paper

\section{Giriş}

Tüm örgütleri etkileyen, teknolojik gelişmelerin ve küreselleşmenin belirginleşmesiyle hem ulusal hem de uluslararası boyutlarda hızlı bir değişim ve dönüşüm yaşanmaktadır. Örgüt yapılarının artık daha esnek, yatay konumlanma önceliği olan, bireylerarası iletişimin arttığı, işgörenin kontrol mekanizmalarını kendileri koyduğu, örgüt içi ağ yapılarının önem kazandığı bir yapıya dönüşme eğilimi vardır. Her ne kadar örgütlerin dış çevreyle düzenli bir ilişki kurması gerekli olsa da, kendi içinde düzenli ve olumlu ilişkiler kuramayan bir örgütün dış çevreyle iyi ilişkiler içinde olması beklenemez (Topaloğlu, 2010). O halde örgütler öncelikle bu işe kendi iç çevresi yani insan kaynağı ile başlamalıdır. Nitekim güven olgusu, hem örgütün dış çevresi hem de örgütün iç çevresi açısından büyük önem taşımaktadır (Tüzün, 2007).

Örgütsel güven ile ilgili birçok tanım yapılmıştır. Örneğin, Matthai’ye göre örgütsel güven, işgörenlerin belirsiz veya riskli bir durumla karşılaş̧ıklarında örgütün taahhütlerinin ve davranışlarının tutarlı olduğuna dair inançlarını ifade etmektedir. Diğer bir tanımda ise, risk taşıyan durumlarda bile bireyin örgütün kendisini etkileyecek uygulama ve politikalardan hem emin olması hem de bunları desteklemesidir (Demircan ve Ceylan, 2003). Ancak, örgütsel güveni sadece kurumsal bakış açısıyla ele almak doğru değildir. Öyle ki güven, hem birey hem de örgüt düzeyinde oluşur, dolayısıyla kişiye ve örgüte yönelik farklı güven düzeyleri olabilir. Bu çerçevede, örgütsel güvenin örgütün kimliğine veya kişiliğine olan güveni temsil ettiğini ve bunun küçük örgütler için örgüt sahibinin kişiliğinden, merkezileşmiş yapıdan veya örgüt kültüründen kaynaklanabileceği belirtilmektedir (Çıtır ve Kavi, 2010: 233).

Örgütsel açıdan güven, kurum içinde yapıcı insan ilişkileri ve kurum başarısını sağlamada belki de en önemli değerlerden birisidir. Güven, kurumsal başarı için önemli bir gereksinimdir. Kurumların yaşadıkları değişim sürecinde işgörenin ancak kurumlarına, çalışma arkadaşları ve yöneticilerine güvendikleri sürece bu değişimleri destekleyebileceklerini ve yaşadıkları onca stres ve pozisyon değişimlerini kabullenip yeni bir kurum yapısı için uğraşabileceklerini savunmuştur. Bazı araştırmalar, güvenin kurum içinde sürtüşmeleri azaltıp rahat ve uyumlu bir ortam yaratarak kurum başarısında önemli bir rol oynadığını ortaya çıkarmıştır. Ayrıca, güven kurumların rekabetçi gücünü arttırmaktadır. Bununla birlikte bazı araştırmacılar da iş (transaction) maliyetlerini azalttığını (Barney ve Hansen, 1994), örgütsel öğrenmeyi (Bouty, 2000) ve bilgi paylaşımını arttırıp, yenilikçiliği desteklediğini (Cooke ve Wills, 2000) ve kurumların mali gücünü (Waddock ve Graves, 1997) yükselttiğini açıklamışlardır(İslamoğlu, Birsel ve Börü, 2007: 22).

Örgütsel açıdan güvenilir bir ortam yaratmak için örgütün her kademesinde işgören çaba göstermelidir. Güven kavramının bir süreç ve ortak çalışmanın ürünü olduğu açıktır. Bu 
durumu Brownell (2000), güven olgusunu örgüt içinde ancak bir sürece bağlı olarak gelişebileceği ve yerleşebileceği şeklinde ifade etmiştir. Brownell, güveni muhafaza etme, sorumlulukları ve sözleri yerine getirmektir. Güven, açık olma, doğru söyleme, dürüstlüğü paylaşarak açı iletişim kurmaktır. Güven, dinleme, saygı gösterme, adil ve tutarlı olma, mazeretlerden ve suçlamalardan kaçınma, işbirliği ve yardım için hevesli olma, yaptığı işten sorumlu olma gibi öğelerin örgütsel güveni oluşturmada ve yerleştirmede kullanılabileceğinin üzerinde durmuştur (Tüzün, 2006: 32).

Diğer yandan güven duygusu üst seviyede olan örgütlerde özellikle alt seviyedeki işgörene daha fazla sorumluluk verildiği ve kararlara katılımların teşvik edildiği, ancak güven duygusu daha düşük olan örgütlerde ise işgörenin çerçevesi sınırlandırılmış rollerle kısıtlandığ 1 görülmektedir. Diğer bir ifadeyle kendisine yönelik güveni düşük seviyede algılayan işgörenden yüksek bir iş performansı beklemek ne kadar yanlışsa, tersi durumdaki işgören için ise yüksek seviyede motivasyon ve verimlilik beklemek o kadar doğrudur (Akyel, 2014).

Çünkü güven düzeyi yüksek bireylerin iş doyumu, örgütsel adalet algısı, örgütü ile özdeşleşmesi, örgüte bağlılığı, örgütsel vatandaşlık davranışlarını gösterme eğilimi, inisiyatifi ele alma davranışı, morali, problem çözme becerisi, risk alma davranışı, sosyal sorumluk alma davranışı ve yaratıcıllğı, güven algısı ile doğru orantılı olarak artmaktadır. Buna karşı1ık örgütsel stres, çatışma yaşanma eğiliminde güven algısı düzeyi ile ters bir orantı olduğu rahatlıkla ileri sürülebilir (Polat, 2007). Dolayısıyla güvenli bireyler, hem fiziksel sermaye, hem de beşeri sermaye birikiminin sağlanmasına ve yaratıcılığın gelişmesine yönelik daha güçlü bir eşgüdüme sahiptirler. Bu noktadan hareketle işgörenlerin örgütlerine yönelik güven algılarının belirlenmesi, diğer (iş tatmini, bağl1lık, adalet vs.) örgütsel davranışların açıklanmasında da bir etken olmaktadır. Çalışmada esas olarak, işgörenlerin örgütsel güven algıları ve örgütsel güvenin alt boyutları incelenmiştir. Ayrıca, örgütsel güven ve katılımcıların demografik özelliklerin ilişkisi analiz edilecek konular arasindadir.

$\mathrm{Bu}$ çalışmada, üniversitedeki işgörenlerin örgütsel güven algılarının ne düzeyde olduğu sorgulanmıştır. Bu problemden hareketle, çalışmada aşağıdaki alt problemlere de cevap aranmıştır.

- Cinsiyet değişkenine göre örgütsel güven algıları arasında anlamlı bir farklılık var midir?

- Yaş değişkenine göre örgütsel güven algıları arasında anlamlı bir farklı1ık var midir?

- Medeni durum değişkenine göre örgütsel güven algıları arasında anlamlı bir farklılık var midır?

- Öğrenim durumu değişkenine göre örgütsel güven algıları arasında anlamlı bir farklılık var midir?

- Hizmet yılı değişkenine göre örgütsel güven algıları arasında anlamlı bir farklılık var midir? 
- Görev yeri değişkenine göre örgütsel güven algıları arasında anlamlı bir farklılık var midir?

- Statü değişkenine göre örgütsel güven algıları arasında anlamlı bir farklılık var midir?

- Gelir durumu değişkenine göre örgütsel güven algıları arasında anlamlı bir farklılık var midır?

Yapılan alan yazın taraması ve incelemeler sonucunda, örgütsel güven ve performans değerlendirme ile ilgili çalışmaların son yıllarda yurtdışına benzer şekilde Türkiye'de de önem kazandığı ancak bu çalışmaların henüz yeterli sayı ve düzeye ulaşamadığı anlaşılmaktadır. Bu sebeple, hem örgütsel güvenin ve insan kaynakları uygulamalarından performans değerlendirmenin birbiri ile olan ilişkisi, hem de bunların çeşitli demografik değişkenlerle olan ilişkilerinin sorgulanması alan yazına katkıda bulunacaktır (Altunkaya, 2011: 85).

Örgütsel güveni yüksek olan işgörenin performans değerlendirme algılamalarının da pozitif anlamda yüksek olması beklenmektedir. Ayrıca, örgütsel güvenin yüksek olduğu örgütlerde nitelikli işgücünü örgüte çekebilmek ve elde tutabilmek daha kolay olabilecektir. Örgüt içinde duyulan güven, işbirliğini artırarak işgörenin ve yöneticilerin motivasyonunu artırabilir ve böylece işgörenin işlerine daha çok yoğunlaşmaları sonucunda performansları artarken örgütsel başarı da sağlanabilir. Bu araştırmanın sonuçları, hem daha sonra bu konu ile ilgili çalışmalar yapacak araştırmacılara, hem de eğitim kurumlarının kalitesinin arttırılmasına yönelik olarak çalışmalarda bulunan araştırmacılara 1şık tutacaktır (Altunkaya, 2011: 86).

$\mathrm{Bu}$ çalışma örgütsel güven kavramına dikkat çekmiştir. Özellikle yerli alan yazında konuyla ilgili yapılan uygulamaya dönük araştırmaların yetersizliği, kavramsal açıdan teorik alt yapının tam olarak netleşmemesinden kaynaklı olabilir. Özellikle birlikte hareket etme ve gruba uyma davranışlarının yaygın olduğu toplumlarda bu tip çalışmaların farklılık yaratacağından, önemli olduğu düşünülmektedir. Bu farklılıkları daha iyi analiz edebilmek için ülkemizde bu tarz uygulamalı çalışmaların artması gerekmektedir.

$\mathrm{Bu}$ çalışmanın amacı, üniversite işgörenlerin örgütsel güven algılamaları ile demografik özellikleri arasındaki ilişkiyi incelemektir. Bu çerçevede, örgütsel güven alt boyutları olan kuruma güven, yöneticiye güven ve bireylerarası güven ile işgörenlerin çeşitli demografik özellikleri (cinsiyet, yaş, medeni durum, öğrenim durumu, hizmet y1lı, görev yeri, statü, gelir durumu) arasındaki ilişkiler analiz edilmiştir.

\section{Kuramsal Çerçeve}

Güven, bireylerarası ilişkilerde olduğu kadar örgütsel yaşam için de önemlidir. Çünkü insan vücudu için kan ne kadar işlevsel ise, ekonomik ve sosyal hayat, özellikle de çalışma hayatında güven o derece işlevseldir(Ören, 2007: 77).Güven olgusu, sağlıklı bir kişiliğin, bireyler arası ilişkilerin, işbirliğinin ve sosyal ilişkilerde istikrar sağlanmasındaki en önemli unsurdur. Son dönemlerde yönetim bilimciler örgütsel verimliliğin sağlanmasında örgütsel güvenin önemine dikkat çekmişlerdir (Toprak, 2006: 63). 
Güven bireysel ve örgütsel düzeyde oluşur. Ancak kişiye güven ve örgüte güven kavramları birbirinden farklıdır (Doney ve Cannon, 1997: 39). Zaheer vd. 1998) kişiler arası ve örgüte güvenin birbirleriyle ilgili fakat birbirlerinden farklı kavramlar olduğunu ifade etmiş̧lerdir (Nyhan ve Marlowe, 1997: 626). Günlük yaşamda iki kişi arasında oluşan samimi ilişkiler sonucunda ortaya çıkan güven "kişisel güven" olarak nitelendirilirken, özellikle örgütsel ilişkiler alanında ortaya çıkan güven türü ise, örgütsel güven olarak nitelendirilmektedir(Bachmann,2003: 63). Luman (1989)'ın kişisel güven ve örgütsel güven ayrımına göre kişiye güven, kişilerarası farklara dayalıdır ve kişiye özeldir. Örgütsel güven ise kişilerden çok örgütlere odaklıdır (Aktaran Büte,2011: 175).

Alan yazında örgütsel güven üç alt boyutta değerlendirilmektedir: yöneticiye güven, çalışma arkadaşlarına güven ve örgüte güven (Tokgöz ve Seymen, 2013: 62). Bu alt boyutlar aşağıda açıklanmıştır.

Yöneticiye Güven: Örgüt içerisinde yöneticiler, alt kademe işgören tarafından birer rol model olarak görülmektedir. Bir örgütte yöneticiler saygı duyulduğu kadar, güven duyulan kişiler olmak zorundadırlar. Güvenin örgüt geneline yayılmasında bu tür bir anlayışın model olarak görülen yöneticilerden gelmesi önem arz etmektedir. Yöneticilerin yaptıkları hatalar, alt kademede işgörenlerin kendilerine saygıları yanında güvenlerinin de kaybolmasına neden olmaktadır. Zira yöneticilerin tüm davranışları alt kademe ve örgütün diğer çevresi tarafından gözetim altındadır(Omarov, 2009: 14).

Örgütlerde güven ortamının yaratılabilmesi ve sürdürülmesi açısından yöneticilere büyük sorumluluklar düşmektedir. Örgütlerinde güven ortamı yaratabilmek için yöneticilere şu beş davranışta (Whitener, Brodt, Korsgaard ve Werner, 1998) bulunmaları önerilmektedir: (a) tutarlı olma, (b) doğru/dürüst olma, (c) ilgili olma, (d) iletişim becerilerine sahip olma ve (e) yetkiyi paylaşma (Özer vd., 2006: 108). İşgörenden bilgi saklanmaması ve iyi veya kötü konuların paylaşılması sonucunda yöneticinin tutarlılık ve dürüstlük sergilemesi ona güvenilmesini sağlar. İlgili olmak boyutu örgütsel güvenin diğer bir boyutunu oluşturmaktadır. Bu boyut, örgüt üyelerinin liderlerinden ilgi gördüklerinde ve karşı tarafın kendilerinden avantaj sağlama eğilimi olmadığına inandıklarında ortaya çıkar. Bu kapsamda, işgörenine karşı arkadaşça davranan, sorunlarının çözümünde yardımcı olan, yol gösteren, koruyan, destekleyen, cesaretlendiren bir yönetici yardımsever olarak algılanır ve işgören bu tip yöneticilere daha kolay güven geliştirirler(Develioğlu ve Çimen, 2012: 143). Güvenin tutarlı olma boyutu kapsamında, kişilerin söyledikleri ve yaptıklarının, düşündükleri ve söylediklerinin birbiriyle tutarlı olması beklenmekte; zamana ve kişiden kişiye göre söz, tutum ve davranışlarını değiştiren kişilere güvenmenin zor olacağı bilinmektedir. Aksi takdirde, tutarlı olmayan kişilerin aldıkları kararları kendi bireysel çıkarları için saptırabilecekleri düşünülür(Günaydın, 2001). Tutarlılık yöneticinin gelecekteki davranışlarını kestirebilir kılarak, ilişkiler bakımından belirlilik yaratır ve güven algılamasını etkiler (Develioğlu ve Çimen, 2012: 143). Yöneticinin söyledikleri ve yaptıkları arasındaki uyum, dürüstlüğ̈̈, örgütün çıkarlarını kendi çıkarlarının önünde tutması, doğruları görmesi ve söylemesi, gerekli yerde gerekli açıklamaları yapması ve herkes tarafindan anlaşı1ır kılması, yardımseverliği, empati kurabilmesi ve sorunlara serinkanlılıkla yaklaşabilmesi, kontrolü ve yetkiyi işgörenle paylaşmaya hevesli olması, çatışmaları diyalogla çözmeye çalışması ve bunda başarılı olması gibi etmenler yöneticiye olan güveni arttıracaktır (Kılınç, 2010: 45). 
Çalışma Arkadaşlarına Güven: Çalışma arkadaşına güven "çalışma arkadaşının yetkinliğine itimat etme ve onun hakkaniyetli, ahlaklı ve güvenilir davranışlar sergileyeceğine inanma" olarak tanımlanabilir. Bu varsayıma dayanarak, çalışma arkadaşına güvenen kişi çalışma arkadaşının kendisine gerekli bilgileri saklamayacağ 1 veya ona yanlış bilgi vermeyeceği veya hakkında dedikodu çıkarmayacağı yani onu suiistimal etmeyeceği konusunda emindir (İslamoğlu vd., 2007: 37).

Örgütlerde bireyler arasında kolay işbirliğine gidilmesi, yöneticiler ile eşgüdümün kolay sağlanması, değişime çabuk tepki verilebilmesi ve hatta performansın yüksek olmasının temel nedeni güvenin yüksek olmasıdır. Herhangi bir örgütte işgörenler arası güvenin yüksek olup olmadığını anlamak için işgörenlerin işyerlerinde nasıl davrandıkları ve işlerine devamsızlıkları gözlenmelidir (Altunkaya, 2011: 33). Çalışma arkadaşlarına güvenin yüksek olduğu örgütlerde işgörenler işlerine gelmekten hoşlanır, iş yerinde güler yüzlü, yaratıcı ve eğlencelidir. İşgörenler bunun yanı sıra örgütlerinin geleceği adına düşünürler ve gelecek örgütsel hedefler doğrultusunda çalışırlar (Semercioğlu, 2012: 49).

Örgütün Kendisine Güven: Örgüte güven kişilerden çok örgüte odaklı olup, bireylerin, örgütsel ilişkiler ve davranışlar ağından beklentilerini içerir. Bir başka ifade ile örgüte güven, bireyin örgütünün kendi yararına olan eylemlerde bulunacağı ya da en azından bu eylemlerin kendisine zarar vermeyeceği inancıdır. Örgüte güven, üyelerin, örgütün politika ve stratejilerine inancı ve ilişkilerini gelecekte de sürdürme kararlılı̆̆ıdır (Polat, 2009: 14).Örgüte güven, işgörenlerin belirsiz veya riskli bir durumla karşılaştıklarında örgütün taahhütlerinin ve davranışlarının tutarlı olduğuna dair inançlarını ifade eder, işgörenlerin örgütün sağladığı desteğe ilişkin algısıdır (Tokgöz ve Seymen, 2013: 62).

\section{Yöntem}

\subsection{Araștırmanın Modeli}

Ankara ilindeki araştırma izni alınan kamu ve vakıf üniversitelerinin bazılarında görev yapan idari işgörenin, örgütsel güven düzeylerini belirlemek amacıyla betimsel nitelik taşıyan tarama modelindedir. Tarama modeli, geçmişte olmuş ya da halen var olan durumu var olduğu şekilde betimlemeyi amaçlar (Karasar, 2005). Amaca uygun olarak mevcut bilgiler, ilgili alan yazının taranmasıyla sistematik bir şekilde hazırlanarak konu hakkında teorik bir çerçeve oluşturulmuştur. Bununla birlikte araştırma problemine yönelik olarak veri toplama aşamasında Likert ölçeği kullanılmıştır. 


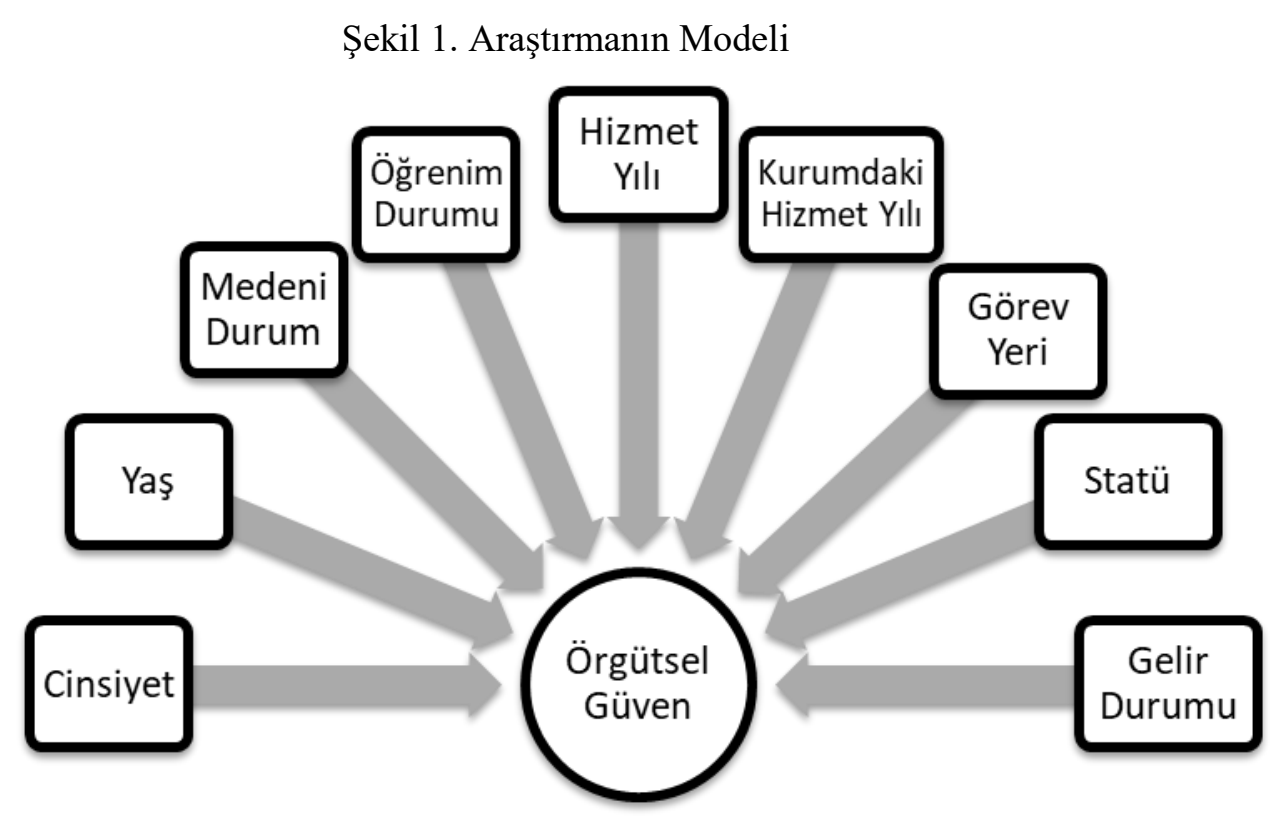

\subsection{Evren ve Örneklem}

Araştırmanın evrenini Ankara'daki devlet ve vakıf üniversitelerinin tüm birimlerinde çalışan toplam 19200 idari işgören, örneklemini ise evren içinden rastgele örnekleme yöntemiyle seçilen 772 gönüllü katılımcı oluşturmuştur. Araştırmalarda örneklemin belirlenmesinde dikkat edilmesi gereken temel unsur, esas alınacak örneğin hedef kitle olarak alınacak yığının özelliklerini yansıtacak nitelikte olmasıdır (Erol ve Tarhan Öztoprak, 2015).

Ankara'daki devlet ve vakıf üniversitelerinde çalışan idari işgören sayısının, üniversitelerin 2013-2014 Eğitim-Öğretim Yılı Faaliyet Raporları ve Bilgi Edinme Kanunu kapsamında edinilen bilgiler doğrultusunda "19200" olduğu belirlenmiştir. Elde edilen bu say1 örneklem formülünde kullanılmıştır (Yamane, 2001,s.116-117). Örneklem bulma işleminin sonucu aşağıda gösterilmiştir.

$\mathrm{Nz2}$ pq

$\mathrm{n}=$

$\mathrm{Nd} 2+\mathrm{z} 2 \mathrm{pq}$

Formulde yer alan sembollerin anlamları:

$\mathrm{n}=$ Ornekleme buyukluğu

$\mathrm{N}=$ Arastırmaya konu evren/yığın

$\mathrm{p}=$ Topluluk oranını veya tahminini 
$\mathrm{q}=1-\mathrm{P}^{\prime} \mathrm{yi}$

$\mathrm{z}=$ Guvenirlik duzeyi

$\mathrm{d}=$ Duyarlıl1k

Formulun Uygulanısı:

$\mathrm{n}=$ Ornekleme buyukluğu

$\mathrm{N}=19200$

$\mathrm{p}=0,5$

$q=0,5$

$\mathrm{z}=1,96$

$\mathrm{d}=0.04$

19200.(1,96)2. $(0,5) .(0,5)$

$\mathrm{n}=$

19200. $(0,04) 2+(1,96) 2 .(0,5) \cdot(0,5)$

$\mathrm{n}=583$ Örneklem hesaplama formülü yardımıyla, örneklem olarak hesaplanmıştır. $\mathrm{Bu}$ sonuca göre, 772 olan örneklem sayısının evreni temsil ettiği kabul edilebilir. Evreni oluşturan üniversitelerde toplam 900 adet anket formu dağıtılmış, 824 adet form geri alınabilmiştir. Geri alınan anketlerden 52 tanesi yanlış ya da eksik doldurma nedeni ile değerlendirmeye alınmamıştır. Geriye kalan 772 adet anket formu değerlendirmeye alınmıştır.

\section{3. Ölçme Araçları}

Araştırmada kullanılacak veri toplama aracı iki bölümden oluşmaktadır: birinci bölüm; işgörenlerin kişisel bilgilerini belirlemeye yönelik ifadelerden oluşturulmuştur. Demografik özellikler bölümü araştırmacı tarafından hazırlanmış olup, cinsiyet, yaş, medeni durum, öğrenim durumu, hizmet yılı, çalış1lan kurumdaki hizmet yılı, görev yeri, statü ve gelir durumu olmak üzere dokuz sorudan oluşmaktadır. Veri toplama aracının ikinci bölümünde; Nyhan ve Marlowe (1997) tarafından geliştirilen ve 12 ifadeden oluşan Örgütsel Güven Envanteri kullanılmıştır. Söz konusu 12 ifadeden ilk sekizi yöneticiye güveni, sonraki dört ifade ise örgüte güveni tespit etmeye yöneliktir. Ayrıca, işgörenler arası güven ölçümü için Cook ve Wall (1990) tarafından geliştirilen ve altı ifadeden oluşan Bireylerarası Güven Ölçeği kullanılmıştır. Araştırmada beşli Likert ölçeği kullanılmıştır. Katılımcılardan ölçekte yer alan ifadeleri 1: Hiç Katılmıyorum, 2: Katılmıyorum, 3: Fikrim Yok, 4: Katılıyorum, 5: Tamamen Katılıyorum şeklinde değerlendirmeleri talep edilmiştir. 
Nyhan ve Marlowe (1997) ölçeğinin kullanıldığı, Köksal (2012)'ın doktora tez çalışmasında, ölçeğin bileşenlerinden yöneticiye güven düzeyinin Cronbach Alfa güvenilirlik katsayısı cinsinden 0,93 değeri, örgütün kendine güven düzeyinin ise 0,85 değeri aldığ tespit edilmiştir. Cook ve Wall (1980) tarafından geliştirilen ve altı ifadeden oluşan bireyler arasın güven ölçeğinin güvenirliği, Köksal (2012) tarafından 0,87 (Cronbach Alfa) olarak tespit etmiştir.

Çalışmada kullanılan ölçeklerin güvenirlik analizi yapılmıştır. Analiz sonucunda Nyhan ve Marlowe (1997)'un ÖGE'nin yöneticiye güven düzeyinin güvenilirlik katsayıs1 (Cronbach Alfa) $\alpha=0,95$, örgütün kendine güven düzeyinin $\alpha=0,88$ ve Cook ve Wall (1990) tarafından geliştirilen BGÖ’nün ise $\alpha=0,93$ olarak hesaplanmıştır (Tablo 4).

Tablo1. Faktöre ait alfa güvenirlik katsay1ları

\begin{tabular}{llll}
\hline & Yöneticiye Güven & Örgütün Kendine Güven & Bireyleraras1 Güven \\
\hline Madde Sayıs1 & 8 & 4 & 6 \\
Cronbach $(\alpha)$ & 0,95 & 0,88 & 0,93 \\
\hline
\end{tabular}

\subsection{Verilerin Toplanması}

Ankara'daki devlet ve vakıf üniversitelerinde çalışan idari işgören sayısı, üniversitelerin 2013-2014 Eğitim-Öğretim Yılı Faaliyet Raporları ve Bilgi Edinme Kanunu kapsamında edinilen bilgiler doğrultusunda belirlenmiştir.

Veri toplama aracının uygulanması aşamasında, çalışma yapılacak üniversitelerin rektörlüklerine ve etik kurullarına izin başvurusu yapılmıştır. Beş devlet (G.Ü., A.Ü., H.Ü., ODTÜ, Y.B.Ü.) ve üç vakıf (Başkent Ü., Ufuk Ü.,) üniversitesi uygulama için izin vermiştir. Bir vakıf (Çankaya Ü.) üniversitesi olumsuz cevap verirken iki vakıf (Bilkent Ü., Atılım Ü.) üniversitesinden ise olumlu ya da olumsuz bir cevap alınamamıştır.

\subsection{Verilerin Analizi}

Araştırmada kullanılan ölçeklerden elde edilen veriler bilgisayar ortamına kodlanıp SPSS 21.0 paket programından yararlanılarak istatistiksel analizler yapılmıştır. Araştırma verilerinin normal dağılım gösterip göstermediğini belirlemek amacıyla Kolmogrov-Smirnov ve Shapiro-Wilk normallik testleri yapılmıştır. Normal dağılım göstermeyen veri setleri için Kurtosis-Skewness değerlerine bakıldı ve değerler $+2 /-2$ arasında bulunduğu için verilerin normal dağılım gösterdiği belirlenmiştir. Betimsel istatistikler için yüzde frekans, ortalama standart sapma puanları ile birlikte, ikili gruplar için t testi, çoklu gruplar için ANOVA analizleri yapılmıştır. Tüm istatistik işlemlerinde anlamlılık $\mathrm{p}<0,05$ olarak kabul edilmiştir.

\section{Bulgular ve Tartışma}

Bu bölümde, "KBF", "ÖGE" ve "BGÖ"den oluşan anketlerden değerlendirmeye alınan 772 adet anket ile toplanan verilerin, SPSS 21,0 istatistik analiz programı aracılığıyla yapılan analizleri, elde edilen bulgulara ve yorumlara yer verilmiştir. 
Tablo 2. İşgörenlerin çalıştıkları üniversite türüne göre dağılımları

\begin{tabular}{lll}
\hline Üniversite & $\mathrm{n}$ & $\%$ \\
\hline Devlet Üniversitesi & 522 & 67,6 \\
Vakıf Üniversitesi & 250 & 32,4 \\
Toplam & 772 & 100,0 \\
\hline
\end{tabular}

İşgörenlerin, çalıştıkları üniversiteye ilişkin bulgular Tablo 2'de verilmiştir. Tablo 2 'de görüldüğü gibi \% 67,6'sının devlet üniversitelerinde, \%32,4'ünün ise vakıf üniversitelerinde görev yaptıkları tespit edilmiştir. Bu sonuca göre katılımcıların büyük bölümünün devlet üniversitesi işgörenlerinden oluştuğu görülmektedir.

Tablo 3.Cinsiyet durumlarına göre dağılımları

\begin{tabular}{lll}
\hline Cinsiyet & $\mathrm{n}$ & $\%$ \\
\hline Kadın & 341 & 44,2 \\
Erkek & 431 & 55,8 \\
Toplam & 772 & 100,0 \\
\hline
\end{tabular}

Yapılan araştırmaya katılanların cinsiyet durumlarına göre dağılımları Tablo 3'deverilmiştir. Tablo 3'de görüldügü̈ gibi ankete katılanların \%44,2'lik kısmını bayanlar, $\% 55,8^{\prime}$ lik kısmını ise erkekler oluşturmaktadır. Buna göre işgörenlerin çoğunluğunu erkekler oluşturmaktadır.

Tablo 4. İşgörenlerin yaş gruplarına göre dağılımları

\begin{tabular}{lll}
\hline Yaş & $\mathrm{n}$ & $\%$ \\
\hline $18-25$ yaş & 62 & 8,0 \\
$26-32$ yaş & 167 & 21,6 \\
$33-39$ yaş & 201 & 26,0 \\
$40-48$ yaş & 263 & 34,1 \\
49 ve üstü & 79 & 10,2 \\
Toplam & 772 & 100,0 \\
\hline
\end{tabular}

İşgörenlerin yaşlarının dağglımı Tablo 4'de gösterilmiştir. Buna göre katılımcıların en yüksek oran ile \%34,1'inin 40-48 yaş aralığında ve en düşük oran ile \%8'inin 18-25 yaş aralığında oldukları görülmektedir. İşgörenlerin 26-32 yaş aralığındaki işgörenin oranı \% 21,6, 33-39 yaş aralığındaki işgörenin oranı \%26,0 iken 49 ve üzeri yaş grubuna dâhil olan işgörenin oranı ise \%10,2 olarak hesaplanmıştır.

Tablo 5. İşgörenlerin medeni durumlarına göre dağılımları

\begin{tabular}{lcl}
\hline Medeni Durum & $\mathrm{n}$ & $\%$ \\
\hline Evli & 560 & 72,5 \\
Bekâr & 212 & 27,5 \\
Toplam & 772 & 100,0 \\
\hline
\end{tabular}

Tablo 5'de işgörenlerin medeni durumlarına göre dağ 11 ımı verilmiştir. Dağılım incelendiğinde, İşgörenlerin 560'ının $(\%$ 72,5) evli, 212' sinin $(\% 27,5)$ bekâr olduğu belirlenmiştir. Buna göre ankete katılanların çoğunluğunu evliler oluşturmaktadır. 
Tablo 5. Eğitim Durumlarına Göre Dağılımları

\begin{tabular}{lll}
\hline Eğitim Durumu & $\mathrm{n}$ & $\%$ \\
\hline İlköğretim & 24 & 3,1 \\
Lise & 186 & 24,1 \\
Ön lisans & 168 & 21,8 \\
Lisans & 326 & 42,2 \\
Lisansüstü & 68 & 8,8 \\
Toplam & 772 & 100,0 \\
\hline
\end{tabular}

İşgörenlerin öğrenim durumlarına göre dağılımları Tablo 5'de gösterilmiştir. Buna göre $\% 42,2$ ile en yüksek oranda katılım lisans mezunları, $\% 3,1$ ile en düşük ilköğretim mezunları. Lisansüstü öğrenime sahip işgörenin oran1 $\% 8,8$, ön lisans düzeyinde öğrenime sahip işgörenin oran $\% 21,8$ ve lise düzeyinde öğrenime sahip işgörenin oranı $\% 24,1$ dir.

Tablo 6. Hizmet y1lına göre dağılımları

\begin{tabular}{lcc}
\hline Hizmet Y1lı (İs Hayat1) & $\mathrm{n}$ & $\%$ \\
\hline $0-4$ Yil & 123 & 15,9 \\
5-9 Y1l & 152 & 19,7 \\
10-14 Y1l & 129 & 16,7 \\
15-19 Y1l & 176 & 22,8 \\
20 Yil ve üstü & 192 & 24,9 \\
Toplam & 772 & 100,0 \\
\hline
\end{tabular}

Araştırmaya katılanların hizmet yılı (iş hayatı) dağılımı Tablo 6' da gösterilmiştir. Buna göre araştırmaya katılanların 123 kişi ile \%15,9'u (0-4 yıl), 152 kişi ile \%19,7'si (5-9 yıl), 129 kişi ile \%16,7'si (10-14 y1l), 176 kişi ile \%22,8'i (15-19 y1l), 192 kişi ile \%24,9'u (20-+ yıl) görev yapmışlardır. Katılımcıların hizmet yılı dağılımı incelendiğinde işgörenin çoğunluğunun 15 yıldan uzun süredir iş hayatında oldukları görülmektedir.

Tablo 7. İşgörenlerin bulundukları kurumdaki hizmet yılına göre dağılımları

\begin{tabular}{lll}
\hline Hizmet Y1lı (Bulunduğu Kurum) & $\mathrm{n}$ & $\%$ \\
\hline 0-4 Yil & 200 & 25,9 \\
5-9 Yil & 198 & 25,6 \\
10-14 Y1l & 109 & 14,1 \\
15-19 Y1l & 143 & 18,5 \\
20 Y1l ve üstü & 122 & 15,8 \\
Toplam & 772 & 100,0 \\
\hline
\end{tabular}

Katılımcıların hizmet y1lı (bulunduğu kurum) dağılımı Tablo 7'de gösterilmiştir. Buna göre araştırmaya katılanların 200 kişi ile \%25,9'u (0-4), 198 kişi ile \%25,6'sı (5-9), 109 kişi ile \%14,1'i (10-14), 143 kişi ile \%18,5'i (15-19), 122 kişi ile \%15,8'i (20-+) y1l görev yapmışlardır. Örgütteki hizmet y1lı dağılımı incelendiğinde hizmet y1lı 0-4 ile 5-9 arası olan işgörenlerin hemen hemen aynı oranla çoğunluğu oluşturduğu görülmektedir.

Tablo 8. İşgörenlerin görev yaptıkları birimlere göre dağılımları

\begin{tabular}{lll}
\hline Görev Yeri & $\mathrm{n}$ & $\%$ \\
\hline Rektörlük Merkez Birimleri & 278 & 36,0 \\
Fakülteler & 295 & 38,2 \\
Yüksekokullar & 62 & 8,0 \\
Enstitüler & 26 & 3,4 \\
Meslek Yüksekokulları & 21 & 2,7
\end{tabular}




\begin{tabular}{lll} 
Diğer & 90 & 11,7 \\
Toplam & 772 & 100,0 \\
\hline
\end{tabular}

Araştırmaya katılanların \%36'lık kısmı rektörlük merkez birimlerinde, \%38,2'lik kısmı fakültelerde, \%8'lik kısmı yüksekokullarda, \%3,4'lük kısmı enstitülerde, \%2,7'lik kısmı meslek yüksekokullarında ve \%11,7’lik kısmı diğer birimlerde görev yaptıkları görülmüştür. Tablo 8'de görüldüğü gibi araştırmaya katılanların \%38,2'lik oranla çoğunluğu fakültelerde görev yapmaktadır.

Tablo 9. Statülerine göre dağılımları

\begin{tabular}{lll}
\hline Statü & $\mathrm{n}$ & $\%$ \\
\hline Orta ve Üst Düzey Yönetici & 36 & 4,7 \\
Şef & 60 & 7,8 \\
Memur & 586 & 75,9 \\
Tekniker, Teknisyen & 90 & 11,7 \\
Toplam & 772 & 100,0 \\
\hline
\end{tabular}

İşgörenlerin örgütteki statüleri itibari ile dağılımı incelendiğinde; yaklaşık $\% 4,7$ 'sinin orta ve üst düzey yönetici olduğu görülürken, $\% 7,8$ 'inin şef, $\% 75,9$ 'unun memur ve \%11,7'sinin tekniker, teknisyen olduğu tespit edilmiştir. Tablo 13'de da görüldüğü gibi araştırmaya katılanların çoğunluğunu \%75,9'luk oranla memur statüsünde işgören oluşturmaktadır.

Tablo 10. Gelir durumlarına göre dağılımları

\begin{tabular}{lll}
\hline Gelir Durumu & $\mathrm{n}$ & $\%$ \\
\hline $850-1.350$ & 102 & 13,2 \\
$1.351-1.850$ & 114 & 14,8 \\
$1.851-2.350$ & 377 & 48,8 \\
$2.351-2.850$ & 147 & 19,0 \\
2.851 ve üstü & 32 & 4,1 \\
Toplam & 772 & 100,0 \\
\hline
\end{tabular}

İşgörenlerin gelir durumlarına göre dağılımları Tablo 10 'da gösterilmiştir. Buna göre 377 işgören 1.851-2.350 TL gelir düzeyi ile katılımcıların büyük çoğunluğunu $(\% 48,8)$ oluşturmaktadır. Katılımcılar içerisinde 102 işgörenin 850-1.350 TL (\%13,2), 114 işgörenin 1.351-1.850 TL (\%14,8), 147 işgörenin 2.351-2.850 TL (\%19,0) ve 32 işgöreninde $2.851 \mathrm{TL}$ ve üzeri gelire sahip oldukları tespit edilmiştir.

Tablo 11. İşgörenin örgütsel güven ölçeği ve bireylerarası güven ölçeğine ait ortalama ve standart sapma sonuçları

\begin{tabular}{llllll}
\hline & $\mathrm{n}$ & Minimum & Maximum & $\overline{\mathrm{x}}$ & $\mathrm{s.s}$ \\
\hline Yöneticiye Güven & 772 & 1,00 & 5,00 & 3,45 & 1,01 \\
Örgütün Kendisine Güven & 772 & 1,00 & 5,00 & 3,18 & 1,05 \\
Bireyleraras1 Güven & 772 & 1,00 & 5,00 & 3,74 & 0,92 \\
\hline
\end{tabular}

Tablo11 incelendiğinde, üniversitelerde çalışan işgörenlerin "ÖGE” alt boyutlarına ilişkin algıları; "Yöneticiye Güven" alt boyutunda $\bar{x}=3,45$, "Örgütün Kendisine Güven" alt boyutunda $\overline{\mathrm{x}}=3,18$, "Bireylerarası Güven" boyutunda ise $\overline{\mathrm{x}}=3,74$, olarak tespit edilmiştir. $\mathrm{Bu}$ sonuçlara göre işgörenlerin mesai arkadaşlarına yönelik algı düzeylerinin daha yüksek olduğu görülmektedir. 
Tablo12. İşgörenin üniversite türüne göre güven ölçeklerine ilişkin algıları arasındaki farklılığa yönelik t-testi sonuçları

\begin{tabular}{|c|c|c|c|c|c|c|}
\hline & Üniversite & $\mathrm{n}$ & & S.S & $\mathrm{t}$ & $\mathrm{p}$ \\
\hline \multirow{2}{*}{ Yöneticiye Güven } & Devlet Üniversitesi & 522 & 3,244 & 0,995 & \multirow{2}{*}{$-8,729$} & \multirow{2}{*}{$0,000 *$} \\
\hline & Vakıf Üniversitesi & 250 & 3,877 & 0,915 & & \\
\hline \multirow{2}{*}{ Örgütün Kendine Güven } & Devlet Üniversitesi & 522 & 2,945 & 1,013 & \multirow{2}{*}{$-9,611$} & \multirow{2}{*}{$0,000 *$} \\
\hline & Vakıf Üniversitesi & 250 & 3,663 & 0,951 & & \\
\hline \multirow{2}{*}{ Bireylerarası Güven } & Devlet Üniversitesi & 522 & 3,571 & 0,931 & \multirow{2}{*}{$-8,036$} & \multirow{2}{*}{$0,000^{*}$} \\
\hline & Vakıf Üniversitesi & 250 & 4,095 & 0,805 & & \\
\hline
\end{tabular}

*0,05 düzeyinde anlamlıdır.

Tablo- 12'de yapılan t-testi analizi sonuçlarına göre, katılımcıların; "Yöneticiye Güven" $[\mathrm{t}()=8.729 ; \mathrm{p}<.05]$, "Örgütün Kendine Güven" $[\mathrm{t}()=9.611 ; \mathrm{p}<.05]$ ve "Bireylerarası Güven" $[\mathrm{t}()=8.036 ; \mathrm{p}<.05]$ boyutlarına ilişkin puanları, çalışılan üniversite türüne göre anlamlı bir farklılık göstermektedir. Bu farklılığın vakıf üniversitelerinde çalışan işgörenin lehine olduğu belirlenmiştir. Diğer bir ifadeyle tüm alt boyutlarda vakıf üniversiteleri ortalama puanları istatistiksel olarak anlamlı düzeyde yüksek çıkmıştır.

H1: Üniversitelerde idari işgörenlerin cinsiyet değişkenine göre örgütsel güven algıları arasında anlamlı bir farklılık var mıdır?

Tablo13. İşörenin cinsiyet değişkenine göre güven ölçeklerine ilişkin algıları arasındaki farklı1ığa yönelik t-testi sonuçları

\begin{tabular}{lllllll}
\hline & Cinsiyet & $\mathrm{n}$ & & $\mathrm{s.s}$ & $\mathrm{t}$ & $\mathrm{p}$ \\
\hline \multirow{2}{*}{ Yöneticiye Güven } & Kadın & 341 & 3,615 & 0,984 & \multirow{2}{*}{4,104} & \multirow{2}{*}{$0,000^{*}$} \\
& Erkek & 431 & 3,317 & 1,019 & & \\
\hline \multirow{2}{*}{ Örgütün Kendine Güven } & Kadın & 341 & 3,283 & 1,020 & \multirow{2}{*}{2,496} & \multirow{2}{*}{$0,013^{*}$} \\
& Erkek & 431 & 3,094 & 1,064 & & \multirow{2}{*}{0,107} \\
\hline \multirow{2}{*}{ Bireylerarası Güven } & Kadın & 341 & 3,800 & 0,915 & \multirow{2}{*}{1,613} & \multirow{2}{*}{0,109} \\
& Erkek & 431 & 3,692 & 0,931 & & \\
\hline
\end{tabular}

*0,05 düzeyinde anlamlıdır

Tablo 13'de, üniversitelerdeki, işgörenin cinsiyet değişkenine göre “ÖGE’nin” bileşenlerine ilişkin algıları arasındaki farklılıklar incelendiğinde; kadın katılımcıların tüm alt boyutlarda daha yüksek ortalamaya sahip olduğu ve "Yöneticiye Güven" ile "Örgütün Kendine Güven" boyutlarında istatistiksel açıdan anlamlı bir farklılık olduğu belirlenmiştir.

H2: Üniversitelerde idari işgörenlerin yaş değişkenine göre örgütsel güven algılar1 arasında anlamlı bir farklılık var mıdır?

Tablo14. İdari İşgörenin yaş değişkenine göre güven ölçeklerine ilişkin algıları arasındaki farklılığa yönelik ANOVA testi sonuçları

\begin{tabular}{|c|c|c|c|c|c|c|}
\hline & & $\mathrm{N}$ & $\overline{\mathrm{x}}$ & S.S & $\mathrm{F}$ & $\mathrm{p}$ \\
\hline \multirow{5}{*}{ Yöneticiye Güven } & $18-25$ & 62 & 3,730 & 1,037 & \multirow{5}{*}{1,709} & \multirow{5}{*}{0,146} \\
\hline & $26-32$ & 167 & 3,460 & 1,023 & & \\
\hline & $33-39$ & 201 & 3,478 & 1,023 & & \\
\hline & $40-48$ & 263 & 3,368 & 0,963 & & \\
\hline & 49 ve üstü & 79 & 3,400 & 1,096 & & \\
\hline
\end{tabular}




\begin{tabular}{|c|c|c|c|c|c|c|}
\hline & Toplam & 772 & 3,449 & 1,014 & & \\
\hline \multirow{6}{*}{ Örgütün Kendine Güven } & $18-25$ & 62 & 3,500 & 1,020 & \multirow{6}{*}{3,442} & \multirow{6}{*}{$0,008 *$} \\
\hline & $26-32$ & 167 & 3,280 & 1,048 & & \\
\hline & $33-39$ & 201 & 3,203 & 1,034 & & \\
\hline & $40-48$ & 263 & 3,019 & 1,032 & & \\
\hline & 49 ve üstü & 79 & 3,171 & 1,096 & & \\
\hline & Toplam & 772 & 3,177 & 1,048 & & \\
\hline \multirow{6}{*}{ Bireyleraras1 Güven } & $18-25$ & 62 & 3,761 & 0,963 & \multirow{6}{*}{1,974} & \multirow{6}{*}{0,097} \\
\hline & $26-32$ & 167 & 3,755 & 0,886 & & \\
\hline & $33-39$ & 201 & 3,804 & 0,937 & & \\
\hline & $40-48$ & 263 & 3,758 & 0,897 & & \\
\hline & 49 ve üstü & 79 & 3,470 & 1,012 & & \\
\hline & Toplam & 772 & 3,740 & 0,925 & & \\
\hline
\end{tabular}

* 0,05 düzeyinde anlamlıdır.

Araştırmaya katılan işgörenlerin yaş değişkeni açısından örgütsel güven algıları ortalamaları Tablo 14'de verilmiştir. Elde edilen verilere göre "Örgütün Kendine Güven" boyutunda 0,05 önem düzeyinde 18-25 yaş kategorisinde yer alanların lehine anlamlı bir farklılık ortaya çıkmıştır. Ayrıca 18-25 yaş kategorisinde yer alan işgörenlerin tüm boyutlarda daha yüksek ortalamaya,40-48 yaş ile 49 ve üstü yaş kategorisinde yer alan işgörenlerin ise daha düşük güven algısına sahip olduğu belirlenmiştir.

H3: Üniversitelerde idari işgörenin medeni durum değişkenine göre örgütsel güven algıları arasında anlamlı bir farklılık var mıdır?

Tablo15. Medeni durum değişkenine göre güven ölçeklerine ilişkin algıları arasındaki farklılığa yönelik t-testi sonuçları

\begin{tabular}{|c|c|c|c|c|c|c|}
\hline & $\begin{array}{l}\text { eni } \\
\text { Im }\end{array}$ & $\mathrm{n}$ & & S.S & $\mathrm{t}$ & $\mathrm{p}$ \\
\hline \multirow{2}{*}{ Yöneticiye Güven } & Evli & 560 & 3,415 & 1,028 & \multirow{2}{*}{$-1,500$} & \multirow{2}{*}{0,134} \\
\hline & Bekâr & 212 & 3,538 & 0,972 & & \\
\hline \multirow{2}{*}{ Örgütün Kendine Güven } & Evli & 560 & 3,172 & 1,047 & \multirow{2}{*}{$-0,241$} & \multirow{2}{*}{0,810} \\
\hline & Bekâr & 212 & 3,192 & 1,053 & & \\
\hline \multirow{2}{*}{ Bireylerarası Güven } & Evli & 560 & 3,753 & 0,922 & \multirow{2}{*}{0,634} & \multirow{2}{*}{0,526} \\
\hline & Bekâr & 212 & 3,706 & 0,934 & & \\
\hline
\end{tabular}

Tablo-15'de araştırma grubunun medeni durum değişkenine göre ölçeklerden elde ettikleri puanlar arasındaki farklılıkları belirlemek amacıyla yapılan $t$ testi sonuçları verilmektedir. Buna göre, işgörenin "Örgütün Kendine Güven" ve "Bireylerarası Güven" algılarında, medeni durum değişkeni açısından herhangi bir farklılığa rastlanamamıştır ( $>0.05)$. Elde edilen verilere göre Bekâr katılımcıların "Yöneticiye Güven" $(\bar{x}=3,53)$ ve "Örgütün Kendine Güven" ( $\bar{x}=3,19)$ boyutlarında daha yüksek bir algıya sahip oldukları saptanmıştır.

H4: Üniversitelerde işgörenlerin eğitim durumu değişkenine göre örgütsel güven algıları arasında anlamlı bir farklılık var mıdır? 
Tablo16. Eğitim durumu değişkenine göre güven ölçeklerine ilişkin algıları arasındaki farklılığa yönelik ANOVA testi sonuçları

\begin{tabular}{|c|c|c|c|c|c|c|}
\hline Eğitim Durumu & & $\mathrm{n}$ & & S.s & $\mathrm{F}$ & $\mathrm{p}$ \\
\hline \multirow{6}{*}{ Yöneticiye Güven } & İlköğretim & 24 & 3,943 & 0,954 & \multirow{6}{*}{3,677} & \multirow{6}{*}{$0,006^{*}$} \\
\hline & Lise & 186 & 3,302 & 1,084 & & \\
\hline & Ön lisans & 168 & 3,380 & 0,973 & & \\
\hline & Lisans & 326 & 3,481 & 0,985 & & \\
\hline & Lisansüstü & 68 & 3,689 & 0,988 & & \\
\hline & Toplam & 772 & 3,449 & 1,014 & & \\
\hline \multirow{6}{*}{$\begin{array}{l}\text { Örgütün } \\
\text { Güven }\end{array}$} & İlköğretim & 24 & 3,542 & 1,029 & \multirow{6}{*}{2,415} & \multirow{6}{*}{$0,047^{*}$} \\
\hline & Lise & 186 & 3,247 & 1,069 & & \\
\hline & Ön lisans & 168 & 3,001 & 1,036 & & \\
\hline & Lisans & 326 & 3,173 & 1,035 & & \\
\hline & Lisansüstü & 68 & 3,313 & 1,049 & & \\
\hline & Toplam & 772 & 3,177 & 1,048 & & \\
\hline \multirow{6}{*}{ Bireylerarası Güven } & İlköğretim & 24 & 3,868 & 0,761 & \multirow{6}{*}{1,602} & \multirow{6}{*}{0,172} \\
\hline & Lise & 186 & 3,778 & 0,963 & & \\
\hline & Ön lisans & 168 & 3,596 & 0,944 & & \\
\hline & Lisans & 326 & 3,797 & 0,867 & & \\
\hline & Lisansüstü & 68 & 3,676 & 1,067 & & \\
\hline & Toplam & 772 & 3,740 & 0,925 & & \\
\hline
\end{tabular}

* 0,05 düzeyinde anlamlıdır.

Tablo 16'da ÖGE'nin alt boyutları işgörenin eğitim durumu bakımından incelendiğinde; "Yöneticiye Güven" $\mathrm{F}=3,67, \mathrm{p}>0,05$ ve "Örgütün Kendine Güven" boyutlarında $\mathrm{F}=2,41, \mathrm{p}>0,05$ 'e göre anlamlı farklılık olduğu tespit edilmiştir. Bu anlamlı farklılık, ilköğretim mezunu olan işgörenin örgütsel güven algılarının daha yüksek olmasından kaynaklanmaktadır. Bununla birlikte BGÖ’ye yönelik olarak, eğitim durumu değişkenine göre anlamlı bir farklılık yoktur.

H5: Üniversitelerdeki işgörenlerin hizmet y1lı değişkenine göre örgütsel güven algıları arasında anlamlı bir farklılık var mıdır?

Tablo 17. Hizmet yılı değişkenine göre güven ölçeklerine ilişkin algıları arasındaki farkl11ı̆̆a yönelik anova testi sonuçları

\begin{tabular}{|c|c|c|c|c|c|c|}
\hline Hizmet & Y1li & $\mathrm{n}$ & & S.S & $\mathrm{F}$ & $\mathrm{p}$ \\
\hline \multirow{6}{*}{ Yöneticiye Güven } & $0-4 Y_{11}$ & 123 & 3,793 & 0,977 & \multirow{6}{*}{4,721} & \multirow{6}{*}{$0,001 *$} \\
\hline & 5-9 Yil & 152 & 3,437 & 1,033 & & \\
\hline & 10-14 Y1l & 129 & 3,344 & 1,033 & & \\
\hline & 15-19 Yil & 176 & 3,319 & 1,030 & & \\
\hline & 20 Yıl ve üstü & 192 & 3,428 & 0,952 & & \\
\hline & Toplam & 772 & 3,449 & 1,014 & & \\
\hline \multirow{5}{*}{$\begin{array}{l}\text { Örgütün } \\
\text { Güven }\end{array}$} & $0-4 Y_{11}$ & 123 & 3,547 & 0,988 & \multirow{5}{*}{6,671} & \multirow{5}{*}{$0,000 *$} \\
\hline & $5-9$ Y1l & 152 & 3,296 & 1,053 & & \\
\hline & 10-14 Y1l & 129 & 3,068 & 1,005 & & \\
\hline & 15-19 Y1l & 176 & 2,979 & 1,076 & & \\
\hline & 20 Yil ve üstü & 192 & 3,103 & 1,024 & & \\
\hline
\end{tabular}




\begin{tabular}{lllllll}
\hline & Toplam & 772 & 3,177 & 1,048 & & \\
\cline { 1 - 5 } Bireylerarasi Güven & 0-4 Y1 & 123 & 3,904 & 0,878 & & \\
& 5-9 Y1l & 152 & 3,773 & 0,955 & & \\
& 10-14 Y1l & 129 & 3,695 & 0,884 & 1,393 & 0,235 \\
& 15-19 Y1l & 176 & 3,698 & 0,945 & & \\
& 20 Y1l ve üstü & 192 & 3,679 & 0,934 & & \\
& Toplam & 772 & 3,740 & 0,925 & & \\
\hline
\end{tabular}

* 0,05 düzeyinde anlamlıdır.

Tablo-17'de, araştırma kapsamına alınan işgörenin hizmet süreleri açısından "ÖGE" alt boyutları ve "BGÖ”ye ait algıları arasındaki anlamlı farklılık incelenmiştir. Buna göre; "Yöneticiye Güven" $\mathrm{F}=4,72, \mathrm{p}<, 05$ ve "Örgütün Kendine Güven" alt boyutuna ait algıları arasında $\mathrm{F}=6,67, \mathrm{p}<, 05$ 'e göre anlamlı bir farklılık olduğu görülmektedir. $\mathrm{Bu}$ anlamlı farklılık; "0-4 Y1l" hizmet süresine sahip olan işgörenin daha yüksek ortalamaya sahip olmasından kaynaklanmaktadır.

H6: Üniversitelerdeki işgörenlerin görev yaptığı birim değişkenine göre örgütsel güven algıları arasında anlamlı bir farklılık var mıdır?

Tablo18. Görev yaptığı birim değişkenine göre güven ölçeklerine ilişkin algıları arasındaki farklı1ığa yönelik ANOVA testi sonuçları

\begin{tabular}{|c|c|c|c|c|c|c|}
\hline & Görev Yaptığı Birim & $\mathrm{n}$ & & S.S & $\mathrm{F}$ & $\mathrm{p}$ \\
\hline \multirow{7}{*}{ Yöneticiye Güven } & Rektörlük Merkez Birimleri & 278 & 3,415 & 1,013 & \multirow{7}{*}{0,851} & \multirow{7}{*}{0,514} \\
\hline & Fakülteler & 295 & 3,413 & 0,984 & & \\
\hline & Yüksekokullar & 62 & 3,423 & 0,981 & & \\
\hline & Enstitüler & 26 & 3,697 & 1,382 & & \\
\hline & Meslek Yüksekokulları & 21 & 3,583 & 1,266 & & \\
\hline & Diğer & 90 & 3,585 & 0,949 & & \\
\hline & Toplam & 772 & 3,449 & 1,014 & & \\
\hline \multirow{7}{*}{$\begin{array}{l}\text { Örgütün } \\
\text { Güven }\end{array}$} & Rektörlük Merkez Birimleri & 278 & 3,103 & 1,068 & \multirow{7}{*}{2,243} & \multirow{7}{*}{$0,048 *$} \\
\hline & Fakülteler & 295 & 3,141 & 0,999 & & \\
\hline & Yüksekokullar & 62 & 3,113 & 1,139 & & \\
\hline & Enstitüler & 26 & 3,356 & 1,261 & & \\
\hline & Meslek Yüksekokulları & 21 & 3,595 & 1,169 & & \\
\hline & Diğer & 90 & 3,425 & 0,944 & & \\
\hline & Toplam & 772 & 3,177 & 1,048 & & \\
\hline \multirow{7}{*}{ Bireylerarası Güven } & Rektörlük Merkez Birimleri & 278 & 3,765 & 0,964 & \multirow{7}{*}{1,681} & \multirow{7}{*}{0,137} \\
\hline & Fakülteler & 295 & 3,716 & 0,867 & & \\
\hline & Yüksekokullar & 62 & 3,487 & 1,098 & & \\
\hline & Enstitüler & 26 & 3,699 & 0,993 & & \\
\hline & Meslek Yüksekokulları & 21 & 3,825 & 1,014 & & \\
\hline & Diğer & 90 & 3,911 & 0,788 & & \\
\hline & Toplam & 772 & 3,740 & 0,925 & & \\
\hline
\end{tabular}

* 0,05 düzeyinde anlamlıdır.

Tablo-18 incelendiğinde üniversitelerdeki işgörenlerin görev yaptığı birime göre "Örgütün Kendine Güven” alt boyutunda anlamlı bir farkl1lık olduğu görülmektedir. 
Katılımcıların görev yaptığı birime göre "BGÖ'ye" ait ortalamaları arasında anlamlı bir farklılığa rastlanmazken, Meslek Yüksekokulları $(\overline{\mathrm{x}}=3,82)$ ve diğer (Spor Merkezi, Araştırma ve Uygulama Merkezleri, Kurullar, Komisyonlar gibi) birimlerde $(\bar{x}=3,91)$ işgörenin daha yüksek ortalamaya sahip olduğu belirlenmiştir.

H7: Üniversitelerde idari işgörenin statü değişkenine göre örgütsel güven algıları arasında anlamlı bir farklılık var mıdır?

Tablo 19. Statü değişkenine göre güven ölçeklerine ilişkin algıları arasındaki farklıllğa yönelik ANOVA testi sonuçları

\begin{tabular}{cllllll}
\hline \multicolumn{1}{c}{ Statü } & & $\mathrm{n}$ & & $\mathrm{s} . \mathrm{s}$ & $\mathrm{F}$ & $\mathrm{p}$ \\
\hline & Orta ve üst düzey yönetici & 36 & 3,788 & 0,976 & & \\
& Şef & 60 & 3,273 & 1,031 & & \\
Yöneticiye Güven & Memur & 586 & 3,471 & 0,997 & 2,833 & $0,037^{*}$ \\
& Tekniker, Teknisyen & 90 & 3,286 & 1,092 & & \\
& Toplam & 772 & 3,449 & 1,014 & & \\
\hline \multirow{5}{*}{ Örgütün Kendine } & Orta ve üst düzey yönetici & 36 & 3,542 & 1,001 & & \\
Güven & Şef & 60 & 3,113 & 0,974 & & \\
& Memur & 586 & 3,174 & 1,043 & \multirow{2}{*}{1,708} & 0,164 \\
& Tekniker, Teknisyen & 90 & 3,097 & 1,133 & & \\
& Toplam & 772 & 3,177 & 1,048 & & \\
\hline \multirow{5}{*}{ Bireylerarası Güven } & Memur & 36 & 4,051 & 0,947 & & \\
& Şef ve üst düzey yönetici & 60 & 3,711 & 0,866 & & \\
& Tekniker, Teknisyen & 586 & 3,734 & 0,922 & \multirow{2}{*}{1,531} & 0,205 \\
& Toplam & 90 & 3,676 & 0,964 & & \\
\hline
\end{tabular}

* 0,05 düzeyinde anlamlıdır.

Tablo-19'da Örgütsel Güveni oluşturan boyutların görev yapılan statü bakımından farkl1lık gösterip göstermediğini test eden bulgular incelendiğinde, "Yöneticiye Güven" boyutunda $\mathrm{F}=2,83, \mathrm{p}<, 05$ 'e göre anlamlı fark olduğu ve sonuca, orta ve üst düzey yönetici (Daire Başkan1, Fakülte/Enstitü/Yüksekokul/Meslek Y.O. Sekreteri, Şube Müdürü gibi) olarak görev yapan işgörenin $(\bar{x}=3,78)$ algı düzeyinin diğer statüde çalışan işgörenden daha yüksek olmasının sebep olduğu tespit edilmiştir.

H8: Üniversitelerde idari işgörenin gelir durumu değişkenine göre örgütsel güven algıları arasında anlamlı bir farklılık var mıdır?

Tablo 20. Aylık gelir durumu değişkenine göre güven ölçeklerine ilişkin algıları arasındaki farklıı̆ğa yönelik ANOVA testi sonuçları

\begin{tabular}{lllllll}
\hline & Gelir Durumu & $\mathrm{n}$ & & $\mathrm{s} . \mathrm{s}$ & $\mathrm{F}$ & $\mathrm{p}$ \\
\hline & $850-1.350$ & 102 & 3,707 & 1,069 & & \\
& $1.351-1.850$ & 114 & 3,686 & 0,962 & & \\
Yöneticiye Güven & $1.851-2.350$ & 377 & 3,375 & 1,003 & \multirow{2}{*}{4,728} & $0,001^{*}$ \\
& $2.351-2.850$ & 147 & 3,294 & 0,966 & & \\
& 2.851 ve üstü & 32 & 3,355 & 1,114 & & \\
& Toplam & 772 & 3,449 & 1,014 & & \\
\hline
\end{tabular}




\begin{tabular}{|c|c|c|c|c|c|c|}
\hline \multirow{6}{*}{$\begin{array}{l}\text { Örgütün } \\
\text { Güven }\end{array}$} & $850-1.350$ & 102 & 3,434 & 1,075 & \multirow{6}{*}{5,609} & \multirow{6}{*}{$0,000^{*}$} \\
\hline & $1.351-1.850$ & 114 & 3,436 & 0,983 & & \\
\hline & $1.851-2.350$ & 377 & 3,135 & 1,045 & & \\
\hline & $2.351-2.850$ & 147 & 2,939 & 1,013 & & \\
\hline & 2.851 ve üstü & 32 & 3,031 & 1,094 & & \\
\hline & Toplam & 772 & 3,177 & 1,048 & & \\
\hline \multirow{6}{*}{ Bireylerarası Güven } & $850-1.350$ & 102 & 4,083 & 0,891 & \multirow{6}{*}{5,203} & \multirow{6}{*}{$0,000^{*}$} \\
\hline & $1.351-1.850$ & 114 & 3,829 & 0,910 & & \\
\hline & $1.851-2.350$ & 377 & 3,680 & 0,899 & & \\
\hline & $2.351-2.850$ & 147 & 3,594 & 0,933 & & \\
\hline & 2.851 ve üstü & 32 & 3,708 & 1,097 & & \\
\hline & Toplam & 772 & 3,740 & 0,925 & & \\
\hline
\end{tabular}

* 0,05 düzeyinde anlamlıdır.

Tablo 20'de "BGÖ’ye" ait işgörenlerin algıları ile aylık gelir durumu arasında $\mathrm{F}=5,20, \mathrm{p}>, 05$ 'e göre anlamlı bir farklılık olduğu tespit edilmiştir. Elde edilen bulgular 1şığında elde edilen gelir düştükçe yöneticiye olan güvenin arttığı gözlemlenmiştir. Araştırma kapsamına alınan işgörenlerin "ÖGE" alt boyutlarına ait algıları aylık gelir durumuna göre analiz edildiğinde, "Yöneticiye Güven" ve "Örgütün Kendine Güven" alt boyutlarında istatiksel olarak anlamlı farklılık saptanmıştır. Her iki alt boyutta da ( $\bar{x}=3,70$ ve $\overline{\mathrm{x}}=3,43$ ) ortalama ile "850-1.350" kategorisinde yer alan işgörenlerin daha yüksek güven düzeyinde olduğu belirlenmiştir.

\section{Sonuç ve Tartışma}

Araştırma sonucunda elde edilen demografik bulgular incelendiğinde, işgörenlerin büyük çoğunluğunu Devlet Üniversitelerinde çalışanlar oluşturmaktadır. İdari işgörenlerin önemli bir kısmını cinsiyete göre erkekler oluşturmaktadır. Araştırmada devlet ve vakıf üniversite idari işgören sayıları eşitlenmeye çalışılsa da devlet üniversitelerinin daha fazla olması nedeni ile eşitlenememiştir. Araştırmada elde edilen verilerin 1şığında üniversitelerdeki idari işgörenin örgütsel güven ölçeğine ait alt boyutlardan aldığı ortalama puanlar incelendiğinde, $(\bar{X}=3,74)$ ortalama ile "Bireylerarası Güven" boyutu ilk sirayı alırken, sırasıyla "Yöneticiye Güven" $(\bar{X}=3,45)$ ve "Örgütün Kendine Güven" boyutu $(\bar{X}=3,18)$ ortalama değer aldığı tespit edilmiştir. Bu sonuçlara göre idari işgörenlerin örgüte güven konusunda algılarının daha az ve mesai arkadaşlarına yönelik algı düzeylerinin daha yüksek olduğu belirlenmiştir. İşgörenlerin kendilerine ve birbirlerine yönelik olarak yüksek derecede güven duymaları çalışma şartlarına olumlu etki eden bir örgütsel iklimin oluşumuna katkı sağlamaktadır. Örgüt yönetimi açısından oldukça olumlu değerlendirilebilecek olan bu ortam, karar almayı ve alınan bu kararların uygulamasını kolaylaştırdığı gibi işgörenin performansını da arttırmaktadır(Madison, 2002). Üniversitelerin idari birimlerinde işgörene yönelik örgütsel güvene ilişkin çalışmalar incelendiğinde, Ülker (2008) "Yöneticiye Güven" $(\bar{X}=3,61)$ ve "Örgütün Kendine Güven" boyutunun $(\bar{X}=3,53)$, Uslu ve Ardıç (2013) Bireylerarası Güven $(\bar{X}=3,86)$, "Yöneticiye Güven" $(\bar{X}=3,43)$ ve "Örgütün Kendine Güven" boyutunun $(\bar{X}=3,21)$ ortalama değer aldığını tespit etmişlerdir. Bu sonuçlar çalışmamızla paralellik arz etmektedir. Kamu örgütlerinin evren olarak alındığı araştırmalarda da (Akyel, 2014; Baş ve Şentürk, 2011) sonuçlarda benzer şekilde örgütsel güven algısı düşük düzeyde kalmıştır. 
İşgörenin üniversite türüne göre güven ölçeklerine ilişkin algıları arasındaki farkl1lı̆̆a yönelik puanları incelendiğinde; vakıf üniversitesinde işgören lehine "Yöneticiye Güven" [t( $)=8.729 ; \mathrm{p}<.05]$, Örgüte Güven" $[\mathrm{t}()=9.611 ; \mathrm{p}<.05]$ ve Bireyleraras1 Güven" $[\mathrm{t}()=8.036 ; \mathrm{p}<.05]$ boyutlarında istatiksel olarak anlamlı bir farkl1lık bulunmuştur. $\mathrm{Bu}$ konuda alan yazında da bu araştırmayı destekleyici çalışmalar bulunmaktadır. Örneğin; Aksoy (2009) yaptığı çalışmada özel sektördeki işgörenlerin çalıştıkları kuruma, kamu sektöründeki işgörenlere göre daha fazla güvendiği ortaya çıkmıştır. Örgütsel davranışların incelendiği araştırmalara da bakıldığında, Ardıç ve Baş'ın (2001) üniversite işgörenlere yönelik olarak yaptıkları çalışmada da vakıf üniversitelerinde akademik işgörenin iş doyumu düzeyleri, kamu üniversiteleri işgörenlerin iş doyumu düzeyinden daha yüksek çıkmıştır. $\mathrm{Bu}$ durumun oluşmasında kamu işgörenlerinin güven konusunda özellikle örgütsel adalet ile ilgili olan ücret, ödül, atama vb. ile ilgili konularda yaşanan sıkıntılardan kaynaklandığı düşünülmektedir. Bu konuda Ülker'in çalışmasında; insanın örgütsel amaçlara etkin bir biçimde yöneltilebilmesi için örgütsel beklentilerinin karşılanması gerekliliğine vurgu yaparak özellikle işgörenin, örgütsel adalet algılamalarının onların örgüte, yöneticiye olan güvenin üzerinde etkili olduğu, örgüte ve yöneticiye güven düzeyinin artırılmasında başta ücret ve ödül sisteminin yeterli düzeyde olmasının gerekliliği üzerinde durmaktadır.

Araştırma kapsamına alınan işgörenlerin cinsiyet değişkenine ilişkin olarak, güven ölçeklerinden elde ettikleri puanlar arasındaki farklılıklar incelendiğinde; kadın işgörenlerin tüm alt boyutlarda erkeklere göre örgütsel güven algılamalarının daha yüksek olduğu ve elde edilen oranların "Yöneticiye Güven" ile "Örgütün Kendine Güven" boyutlarında istatistiksel açıdan anlamlı bir farklılık meydana getirdiği görülmektedir. Bulgulardan hareketle araştırmada, cinsiyet değişkenin örgütsel güven algılamasında önemli bir etken olduğu ortaya çıkmıştır. Örgütsel güven düzeyine yönelik algıların cinsiyete göre farklılaşması bireyin kaygı ve güven motivasyonu ile ilgili olabileceği gibi, cinsiyet rolleri ile de ilişkili olabileceği düşünülebilir (Vekli ve Paliç, 2012). İşcan ve Sayın (2010) ve Akyel (2014)'in yaptığı çalışmada da benzer sonuçlar bulunmuştur. Ancak alan yazında erkeklerin kadınlardan örgüte olan güvenlerinin yüksek olduğu ile ilgili çalışmalarda görülmektedir. Örneğin; Aksoy (2009), Ankara ilindeki işletmelerde yaptığı araştırmada erkek işgörenlerin kuruma güven algılarının kadın işgörenlerden daha yüksek olduğu tespit edilmiştir.

İşgörenlerin yaş değişkenine göre güven ölçeklerine ilişkin algıları arasındaki farklılı̆̆a yönelik puanlar incelendiğinde ise; genç işgörenlerin örgütsel güven düzeylerinin yüksekliği dikkat çekmektedir. 18-25 yaş kategorisinde yer alan işgörenlerin, 40-48 yaş ile 49 ve üstü yaş kategorisinde yer alanlara göre örgütsel güven boyutlarının daha belirgin olmasından hareketle, yaş ve örgütsel güven boyutları arasında negatif bir ilişkinin varlı̆̆ından söz edilebilir. İlgili alan yazın incelendiğinde, Omarov'un (2009) çalışmasında 26-30 yaş grubunda yer alan işgörenlerin, örgütün kendisine güven düzeyleri diğer gruplara kıyasla daha yüksek olduğu görülmektedir. Yine Topaloğlu'nun (2010) çalışmasında da yaş ilerledikçe güven algılamalarının düştüğü görülmektedir. Yapılan bu çalışma ile Omarov ve Topaloğlu'nun çalışmaları da paralellik göstermektedir.

Araştırma kapsamına alınan idari işgörenlerin örgütsel güven boyutları medeni durum değişkeni açısından analiz edildiğinde, anlamlı bir farklılık bulunmamakla birlikte, tüm boyutlarda evli ve bekâr katılımcıların güven algı düzeylerinin eşit seviyede çıktığı saptanmıştır (Tablo 19). Bu sonuçlara göre araştırmada, medeni durum değişkeninin örgütsel güven algısı üzerinde bir etkisi olmadığı belirlenmiştir. Benzer çalışmalar incelendiğinde 
(Joseph ve Winston, 2005; İşcan ve Sayın, 2010; Durukan vd., 2010 ve Akyel, 2013) araştırma sonuçlarının çalışmamızı destekler nitelikte olduğu görülmüştür.

İşgörenlerin öğrenim durumuna göre güven ölçeklerine ilişkin algıları arasındaki farklılığa yönelik puanları incelendiğinde; ilköğretim mezunu olan işgörenlerin"Yöneticiye Güven", "Örgütün Kendine Güven" ve "Bireylerarası Güven", boyutlarına yönelik algılarının diğer eğitim düzeylerinden mezun olan işgörenlere göre, daha yüksek olduğu görülmektedir. Ayrıca bu oranlar "Yöneticiye Güven" $F=3,67, p>0,05$, ve "Örgütün Kendine Güven" boyutlarında F=2,41, p>0,05'e göre anlamlı farklılık yaratmaktadır. Tüzün, Aksoy ve Erden öğrenim düzeyi düşük olan bireylerin öğrenim düzeyi yüksek olan bireylere nazaran örgütsel güvenlerinin daha fazla olduğunu belirtirlerken, İşcan vd. ile Büte (2011) öğrenim seviyesi arttıkça örgütsel güvenin de arttığını tespit etmişlerdir.

Araştırma bulgularına göre üniversitelerde idari işgörenlerin hizmet süresi değişkenine ilişkin olarak, "Yöneticiye Güven" $F=4,71, p<, 05$ ve "Örgütün Kendine Güven" alt boyutuna ait işgören algıları arasında $\mathrm{F}=6,67, \mathrm{p}<, 05$ 'e göre anlamlı bir farklılık olduğu belirlenmiştir. $\mathrm{Bu}$ anlamlı farklılık; "0-4 Y1l” hizmet süresine sahip olan işgörenin daha yüksek ortalamaya sahip olmasından kaynaklanmaktadır. Bununla birlikte, anlamlı bir farklılık olmamasına rağmen Bireylerarası Güven boyutunda yine "0-4 Yil" hizmet süresi kategorisinde yer alan katılımcıların daha yüksek güven algısına sahip olduğu saptanmıştır. Araştırmamızla benzer şekilde Aksoy (2009)'un yaptığı araştırmada hizmet süresi daha az olan personelin örgüte güven algılamalarının, daha yüksek hizmet süresi olanlara göre daha belirgin olduğu görülmektedir. Araştırma sonuçlarına göre mesleki kıdem arttıkça örgütsel güven duygusunun azalması, üniversitelerin idari açıdan yönetimi için oldukça düşündürücüdür, bu durum idari işgörenlerin örgütsel performansını azaltıcı, işten bıkkınlık yaratacak bir durumun oluşmasına etki edebilir. İşgörenlerin ÖGE ve BGÖ’ye ait ortalamalarının görev yaptı̆̆ birime göre karşılaştırıldığında; Meslek Yüksekokulları ve diğer (spor merkezi, araştırma merkezi gibi) birimlerde görev yapan işgörenlerin daha yüksek ortalamaya sahip olduğu belirlenmiştir. Bu sonuç birimlerin farklı iş tanımlarına göre çalışmasından ve birimlerdeki idarecilerin farklı yöneticilik stillerinden kaynaklanabilir. Çalışmada elde edilen verilere göre, görev yaptığı statü değişkenine ilişkin ÖGE'nin bileşenlerini oluşturan boyutlara yönelik aldıkları ortalama puanlar incelenmiştir. Yöneticiye Güven boyutunda $\mathrm{F}=2,83, \mathrm{p}<, 05$ 'e göre anlamlı fark olduğu ve sonuca orta ve üst düzey yönetici olarak görev yapanların $(\bar{X}=3,73)$ algı düzeyinin diğer statüdeki işgörenlerden daha yüksek olmasına sebep olduğu tespit edilmiştir. Ayrıca anlamlı farklılık çıkmamakla birlikte Örgütün Kendine Güven ve Bireylerarası Güven boyutlarında orta ve üst düzey yönetici olarak görev yapanların algı düzeyinin diğer statüde görev yapanlardan daha yüksek bir algılamaya sahip olduğu görülmektedir. Bu konuda çalışmamızla benzer şekilde Omarov (2009) analizinde; daha alt kademede görev yapanların yöneticilerine en az düzeyde güvendiklerini tespit etmiştir.

Çalışma sonuçları, yöneticilerin astları ile güveni içeren bir ilişki içerisinde olmasının önemini ortaya koymaktadır. $\mathrm{Bu}$ açıdan kamu kurumlarında yöneticilerin işgörenlerle açık ve dürüst bir etkileşim içinde olmaları gerekmektedir. Etkin bir iletişim kurmaları gerekli görülmektedir(Ülker, 2008). Araştırmada işgörenlerin gelir durumu değişkenine göre, ÖGE’ye ilişkin algı düzeyleri arasındaki farklılıklar incelenmiştir. Yöneticiye Güven boyutunda ( $\bar{X}=3,77)$, Örgütün Kendine Güven boyutunda $(\bar{X}=3,43)$ ve BGÖ'de $(\bar{X}=4,08)$, oranlariyla, "850-1.350" gelir durumu kategorisinde yer alan 
işgörenlerin daha yüksek güven algısına sahip olduğu ve bu sonucun tüm boyutlarda istatiksel olarak anlamlı farklılık yarattığı tespit edilmiştir. Diğer bir ifadeyle elde edilen gelir düştükçe işgörenin yöneticiye, örgütün kendisine ve çalışma arkadaşlarına olan güvenin arttığı gözlemlenmiştir.

Örgüt sosyal bir sistemdir. İnsan örgütün vazgeçilmez temel unsurudur. İnsanın sadece bir üretim faktörü olarak ele alınıp değerlendirilmesinin yeterli olmadığ bilinen bir gerçektir. Örgütün sosyal ortamı içerisinde birey ve grupların tutum ve davranışları oldukça belirleyicidir. İnsanın sadece bir üretim faktörü olarak ele alınmasının yeterli olmadığı sosyo-psikolojik, kültürel yönleri ile bir bütün olarak ele alınması önem kazanmıştır. İnsanın örgütsel amaçlara etkin bir biçimde yöneltilebilmesi onların örgütsel beklentilerinin karşılanması ile sağlanacaktır (Ülker,2008).

Genel itibariyle örgütsel güven düzeyini yükseltmek için;

- Yönetim, personelin adalet algılarını pozitif yönde etkileyecek karar ve eylemler gerçekleştirmelidir. Eşit işe eşit ücret politikası gütmek, personelin tümüne birden eşit sosyal haklar sağlamak gibi onların eşitliğini öne çıkararak adalet algılamalarını pozitif yönde etkileyecek faaliyetlerde bulunulmalıdır.

- İyi bir iletişim sisteminin örgütte personel ile yönetici arasındaki etkileşim sıklığını artırarak, birbirlerine daha yakın hale gelmesine yardımcı olacağından, personelin örgütsel güven düzeyini yükseltici etkisi bulunmaktadır. Dolayısıyla örgüt yönetimi iyi bir iletişim ve güçlü bir geribildirim sistemini benimsemelidir

Yöneticiye ve örgüte güvenin örgütsel adalet algılaması dışında kalan bazı faktörler açısından da araştırılmasında yarar vardır. Güvenin yaş, cinsiyet, eğitim durumu, hizmet süresi, kişilik özellikleri ve güven doğal eğilimi açısından özellikleri üzerinde durulabileceği gibi güvenilenin liderlik tarzı ve örgüt içindeki pozisyonu üzerinde de çalışılabilir.

\section{Kaynaklar}

Aksoy, M. (2009). "İşletmelerde örgütsel güven anlayışının algılanması ve demografik değişkenler açısından analizi”, Yüksek Lisans Tezi. Gazi Üniversitesi Sosyal Bilimler Enstitüsü. Ankara.

Akyel, Y. (2014). "Örgütsel Adalet ve Örgütsel Güven İlişkisi”, Doktora Tezi, Gazi Üniversitesi Sağlık Bilimleri Enstitüsü, Ankara.

Altunkaya, K. (2011). "Örgütsel Güven ile İnsan Kaynakları Fonksiyonlarından Performans Değerlendirme Arasındaki İlişkinin İncelenmesine Yönelik Bir Uygulama”, Yüksek Lisans Tezi, Yıldız Teknik Üniversitesi Sosyal Bilimler Enstitüsü, İstanbul.

Ardıç K ve Baş T. (2001). "Kamu ve Vakıf Üniversitelerindeki Akademik Personelin İş Tatmin Düzeyinin Karşılaştırılması", 9. Ulusal Yönetim ve Organizasyon Kongresi. İstanbul: 479-484.

Bachmann, R. (2003). "Trust and Power as Means of Coordinating the Internal Relations of the Organization: A Conceptual Framework", in B. Nooteboom and F. Six (eds.), The Trust Process in Organizations. Empirical Studies of the Determinants and the Process of Trust Development (Edward Elgar, Cheltenham): 58-74 
Baş, G. ve Şentürk, C. (2011). "Illköğretim Okulu Öğretmenlerinin Örgütsel Adalet, Örgütsel Vatandaşlık ve Örgütsel Güven Algıları", Kuram ve Uygulamada Eğitim Yönetimi 17, (1): 29-62.

Büte, M. (2011). "Etik İklim, Örgütsel Güven ve Bireysel Performans Arasındaki İlişki”, Atatürk Üniversitesi İktisadi ve İdari Bilimler Dergisi, 25(1): 171-192.

Cook, J. and Wall, T. (1980). "New Work Attitude Measures of Trust, Organizational Commitment and Personal Need Non-Fulfillment", Journal of Occupational Psychology, 53(1): 39-52.

Çıtır, I.Ö., Kavi, E. (2010) “Algılanan Örgütsel Güven İle İş Güvencesi Arasındaki İlişkiye Yönelik Bir Araştırma', Yönetim Bilimleri Dergisi, 8(2), 229-246.

Demircan, N. ve Ceylan, A. (2003), “Örgütsel Güven Kavramı: Nedenleri ve Sonuçları", Celal Bayar Üniversitesi. İ.İ.B.F, Yönetim ve Ekonomi Dergisi, 10(2), 139-150.

Develioğlu, K. ve Çimen, M. (2012). "Örgütsel Güvenin Kaynağı Olarak İşletmelerin Çalışanlara Karşı Sosyal Sorumlulukları”, Uluslararası Alanya İşletme Fakültesi Dergisi, 4(2):141-149.

Doney, Patricia M. and Joseph P. Cannon (1997). "An Examination of The Nature of Trust in Buyer-Seller Relationships", The Journal of Marketing: 35-51.

Durukan S., Akyürek Ç. ve Coşkun E. (2010). "Hacettepe Üniversitesi Erişkin Hastanesinde Çalışan Hemşirelerin Örgütsel Güven, Güçlendirme ve Bağl1lık Düzeylerinin Belirlenmesi", Süleyman Demirel Üniversitesi İ.İ.B.F. Dergisi, 15(3): 411-434.

Erden, A. (2007). "Ankara ve Lefkoşa Okul Yöneticilerinin ve Öğretmenlerinin Örgütsel Güvene İlişkin Görüşleri”' Doktora Tezi, Ankara Üniversitesi Eğitim Bilimleri Enstitüsü.

Erol, Y., Tarhan Öztoprak, M. (2015). "Psikolojik Şiddetin Tükenmişlik Üzerindeki Etkisinde İş StresininAracılık Rolü: Ankara İlindeki Sosyal Güvenlik Kurumuna Bağlı Çalışanlar Üzerinde Bir Analiz', İşletme Araştırmaları Dergisi, 7(2): 96.

Günaydın, S. C. (2001). ' 'İşletmelerde Örgütsel Adalet ve Örgütsel Güven Değişkenlerinin Politik Davranış Algısı ve İşbirliği Yapma Eğilimine Etkisini İnceleyen Bir Çalışma’, Yüksek Lisans Tezi, Marmara Üniversitesi Sosyal Bilimler Enstitüsü, İstanbul.

İslamoğlu, G., Birsel, M. ve Börü, D. (2007). "Kurum İçinde Güven: Yöneticiye, İş Arkadaşlarına ve Kuruma Yönelik Güven Ölçümü :(Alan araştırması ve sonuçları)", İstanbul: İnk1lap Yayınc1lı.

İşcan Ö. F ve Sayın U. (2010). "Örgütsel Adalet, İş Tatmini ve Örgütsel Güven Arasındaki İlişki”, Atatürk Üniversitesi İktisadi ve İdari Bilimler Dergisi, 24(4): 195-216.

Joseph, E. E. ve Winston, B. E. (2005). "A Correlation of Servant Leadership, Leader Trust and Organizational Trust", Leadership and Organization Development Journal, 26(1/2): 6-22.

Karasar, N. (2005). "Bilimsel Araştırma Yöntemi”, Ankara: Nobel Yayıncılık.

Kılınç, A.Ç. (2010). "Okul Yöneticilerinin Etik Liderlik Davranışları Gösterme Düzeyleri ile Öğretmenlerin Yaşadıkları Örgütsel Güven ve Yıldırma Arasındaki İlişki”, Yüksek Lisans Tezi, Gazi Üniversitesi Eğitim Bilimleri Enstitüsü, Ankara.

Köksal O. (2012). "Sosyal Değişim Teorisi Çerçevesinde Güven ve Algılanan Aidiyet Durumunun Örgütsel Vatandaşlık Davranışı ve Saldırgan Davranışlar Üzerine Etkisi”, Doktora Tezi, Erciyes Üniversitesi Sosyal Bilimler Enstitüsü, Kayseri.

Madison, W. (2002). "Organizational Trust Administrator", 21(3): 6.

Nyhan, R. C. ve Marlowe, H. A. (1997). "Development and Psychometric Properties of The Organizational Trust İnventory", Evaluation Review, 21(5): 614-635.

Omarov, A. (2009). “Örgütsel Güven ve İş Doyumu: Özel Bir Sektörde Uygulama”, Yüksek Lisans Tezi, Dokuz Eylül Üniversitesi Sosyal Bilimler Enstitüsü. İzmir. 
Ören, K. (2007). "Sosyal Sermayede "Güven” Unsuru ve İşgücü Performansına Etkisi”, Erciyes Üniversitesi Kamu-İ̉s Dergisi, 9(1): 71-90.

Özer, N., Demirtaş, H., Üstüner, M. ve Cömert, M. (2006). “Ortaöğretim Öğretmenlerinin Örgütsel Güven Algıları”, Ege Üniversitesi Eğitim Fakültesi, Ege Eğitim Dergisi, 7(1): 103-124.

Polat, S. (2007). “'Ortaöğretim Öğretmenlerinin Örgütsel Adalet Algıları, Örgütsel Güven Düzeyleri İle Örgütsel Vatandaşlık Davranışları Arasındaki İlişki”, Doktora Tezi, Kocaeli Üniversitesi, Sosyal Bilimler Enstitüsü, Kocaeli.

Polat, S. (2009). "Eğitim Örgütleri İçin Sosyal Sermaye Örgütsel Güven”, Ankara: Pegem Yayıncilik.

Semercioğlu, M.S. (2012). "Özel ve Kamu Hastanelerinde Çalışan Tıbbi Sekreterlerin İş Doyumu ve Örgütsel Güven Düzeylerinin Karşılaştırılmasına Yönelik Bir Alan Çalışması”, Yüksek Lisans Tezi, Gazi Üniversitesi Eğitim Bilimleri Enstitüsü. Ankara.

Shaw, R.B.(1997). "Trust in balance: building successful organizations on results, Integrity and Concern', San Francisco: Jossey-Boss.

Tokgöz, E. ve Seymen, O.A. (2013). "Örgütsel Güven, Örgütsel Özdeşleşme ve Örgütsel Vatandaşlık Davranışı Arasındaki İlişki: Bir Devlet Hastanesinde Araştırma”, Marmara Üniversitesi Öneri Dergisi,10(39): 61-76. dergi.marmara.edu.tr/maruoneri/article/view/1012000308

Topaloğlu, I., G.(2010). “İşgörenlerin Adalet ve Etik Algıları Açısından Örgütsel Güven İle Örgütsel Bağl1lık İlişkisi’, Yüksek Lisans Tezi, Atılım Üniversitesi Sosyal Bilimler Enstitüsü, Ankara.

Toprak, O. (2006). "Örgütsel Güvenin Performans Üzerindeki Etkisi ve Bankacılık Sektöründe Bir Uygulama”, Yüksek Lisans Tezi, Gaziantep Üniversitesi Sosyal Bilimler Enstitüsü. Gaziantep.

Tüzün, İ., K. (2006). “Örgütsel Güven, Örgütsel Kimlik ve Örgütsel Özdeşleşme İlişkisi; Uygulamalı Bir Çalışma”, Doktora Tezi, Gazi Üniversitesi Sosyal Bilimler Enstitüsü, Ankara.

Tüzün, İ.K. (2007). “'Güven, Örgütsel Güven ve Örgütsel Güven Modelleri’, Karamanoğlu Mehmetbey Üniversitesi, Sosyal ve Ekonomik Araştırmalar Dergisi, Aralık, 93-118.

Uslu, O., Ardıç, K. (2013). "Güç Mesafesi Örgütsel Güveni Etkiler mi', Afyon Kocatepe Üniversitesi İktisadi ve İdari Bilimler Fakültesi Dergisi, 15(2): 313.

Ülker, G. (2008). "Çalışanların Örgütsel Adalet Algılamalarının Yönetici ve Örgüte Duyulan Güven Üzerindeki Etkisi”, Abant İzzet Baysal Üniversitesi Sosyal Bilimler Enstitüsü Dergisi, 1(16): 188-208.

Vekli G.S. ve Paliç V. (2012). "Lise Öğrencilerin Problem Çözme Becerisi Algılarının Belirlenmesi", Journal of Educational and Instructional Studies in the World, 2(1): 89-95.

Yamane, T. (2001). "Temel Örnekleme Yöntemleri” (Birinci Bask1), Çeviren: Alptekin ESEN, M. Akif BAKIR, Celal AYDIN ve Esen GÜRBÜZSEL, İstanbul: Literatür Yayınc1lik.

Whitener, E. M., Brodt, S. E., Korsgaard, M. A. and Werner, J. M. (1998). "Managers as Initiators of Trust: An Exchange Relationship Framework for Understanding Managerial Trustworthy Behavior", Academy of Management Review, 23(3): 513-530.

Zaheer, A., McEvily, B. and Perrone, V. (1998). "Does Trust Matter? Exploring The Effects of Interorganizational and Interpersonal Trust on Performance". Organization Science, 9(2): 141-159. 